\title{
Diversity of Macrophomina phaseolina Based on Morphological and Genotypic Characteristics in Iran
}

\author{
Valiollah Mahdizadeh, Naser Safaie* and Ebrahim Mohammadi Goltapeh \\ Department of Plant Pathology, Faculty of Agriculture, Tarbiat Modares University, Tehran, Iran \\ (Received on September 6, 2010; Accepted on April 17, 2011)
}

\begin{abstract}
Fifty two Macrophomina phaseolina isolates were recovered from 24 host plant species through the 14 Iranian provinces. All isolates were confirmed to species using species-specific primers. The colony characteristics of each isolate were recorded, including chlorate phenotype, relative growth rate at $30^{\circ} \mathrm{C}$ and $37^{\circ} \mathrm{C}$, average size of microsclerotia, and time to microsclerotia formation. The feathery colony phenotype was the most common $(63.7 \%)$ on the chlorate selective medium and represented the chlorate sensitive phenotype of the Iranian Macrophomina phaseolina population. Meantime, inter simple sequence repeats (ISSR) Markers were used to assess the genetic diversity of the fungus. Unweighted pair-group method using arithmetic means (UPGMA) clustering of data showed that isolates did not clearly differentiate to the specific group according to the host or geographical origins, however, usually the isolates from the same host or the same geographic origin tend to group nearly. Our results did not show a correlation between the genetic diversity based on the ISSR and phenotypic characteristics. Similar to the $M$. phaseolina populations in the other countries, the Iranian isolates were highly diverse based on the phenotypic and the genotypic characteristics investigated and needs more studies using neutral molecular tools to get a deeper insight into this complex species.
\end{abstract}

Keywords : charcoal rot, chlorate phenotype, ISSR

The causal agent of charcoal rot, Macrophomina phaseolina (Tassi) Goidanich, is a soil- and seed-borne pathogen of over 500 host plant species (Dhingra and Sinclair, 1978) and it causes significant damage in Iran to soybean (Raeyatpanah and Forootan, 1993; Raeyatpanah et al., 2002) and sunflower (Razavi and Pahlavani, 2004). The high levels of morphological variability of M. phaseolina across different hosts and geographical regions suggest that this species may be divided into subgroups (Aboshosha et

\footnotetext{
* Corresponding author.

Phone) +982148292346, FAX) +982148292200

E-mail)nsafaie@modares.ac.ir
}

al., 2007; Beas-Fernandez et al., 2006; Hawatema and Hameed, 2006; Karunanithi et al., 1999; Mayek-Perez et al., 1997; Mihail and Taylor, 1995; Omar et al., 2007). However, grouping of isolates by formae specialis, subspecies, or physiological race was challenged due to variation in the morphology of isolates from a single host (Dhingra and Sinclair, 1972).

Molecular markers are powerful tools for assessing genetic variation and elucidating genetic relationships within and among species (Chakravarthi and Naravaneni, 2006). Different molecular methods have been used for differentiating $M$. phaseolina populations including Restriction Fragment Length Polymorphism (RFLP) of rDNA-ITS regions (Aghakhani and Dubey, 2009; Almeida et al., 2003; Purkayastha et al., 2006; Su et al., 2001), Random Amplified Polymorphic DNA (RAPD) (Aboshosha et al., 2007; Aghakhani and Dubey, 2009; Almeida et al., 2003; Almeida et al., 2008; Babu et al., 2010; Das et al., 2006; Jana et al., 2003; Omar et al., 2007; Purkayastha et al., Rajkumar and Kuruvinashetti, 2007; Su et al., 2001; 2006; Zade et al., 2009), Amplified Fragment Length Polymorphism (AFLP) (Brooker et al., 2008; Mayek-Perez et al., 2001; Reyes-Franco et al., 2006; Saleh et al., 2010; Vandemark et al., 2000), Universal Rice Primer PCR (URP-PCR) (Jana et al., 2005b), Inter simple sequence repeats (ISSR) (Jana et al., 2005a; Purkayastha et al., 2008), Repetitive SequenceBased Polymerase Chain Reaction (Rep-PCR) (Purkayastha et al., 2008) and SSR (Baird et al., 2010). Inter simple sequence repeat (ISSR) markers are powerful tools which can be utilized to access the variation in the flanking regions of microsatellite loci that are dispersed throughout all genomes (Zietkiewicz et al., 1994). In this study we used some conventional techniques and ISSR markers to assess the morphologic and genetic variability among 52 isolates of $M$. phaseolina from different hosts and origins within Iran and identifying insights to host specialization.

\section{Material and Methods}

Fungal isolates. Isolates of $M$. phaseolina were recovered from 24 different host species showing typical symptoms 


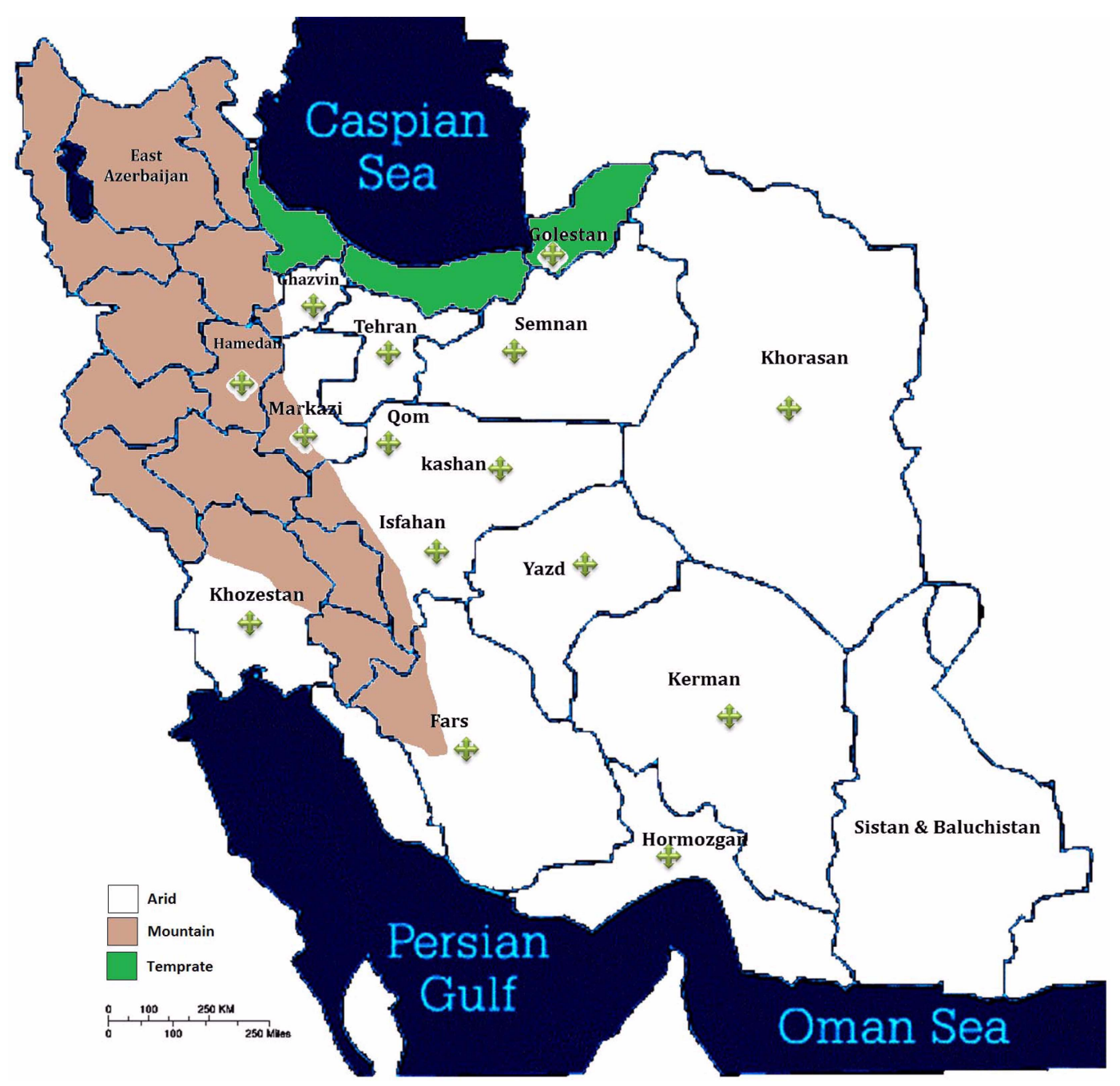

Fig. 1. Iranian provinces where samples, showing charcoal rot, of different host species were collected for Macrophomina phaseolina isolation.

and signs of charcoal rot in 14 Iranian provinces (Fig. 1 and Table 2). To isolate $M$. phaseolina from infected tissue, five small $(0.5 \mathrm{~cm})$ epidermal sections were excised from symptomatic roots or stems. Tissue sections were surface disinfested with $75 \%$ ethanol for $30 \mathrm{~s}$ and $2.5 \%$ sodium hypochlorite for 30 then washed in sterile water for $1 \mathrm{~min}$. and placed on potato dextrose agar (PDA, Merck, Darmstadt, Germany) containing chloramphenicol $(0.1 \mathrm{mg} / \mathrm{ml})$. Plates were incubated at $30^{\circ} \mathrm{C}$ in the dark for 5 days. Pure cultures were obtained by the hyphal tip technique and maintained on sterile toothpicks at room temperature (Edmunds, 1964). Isolates were identified to species using species-specific primers (MpKFI/MpKRI) according to Babu et al. (2007). Controls included a no DNA negative control, DNA of isolates of Trichoderma harzianum, and Cytospora schusleri, Sclerotinia sclerotiorum. A known marker isolate of $M$. phaseolina was used as a positive control (Fig. 2).

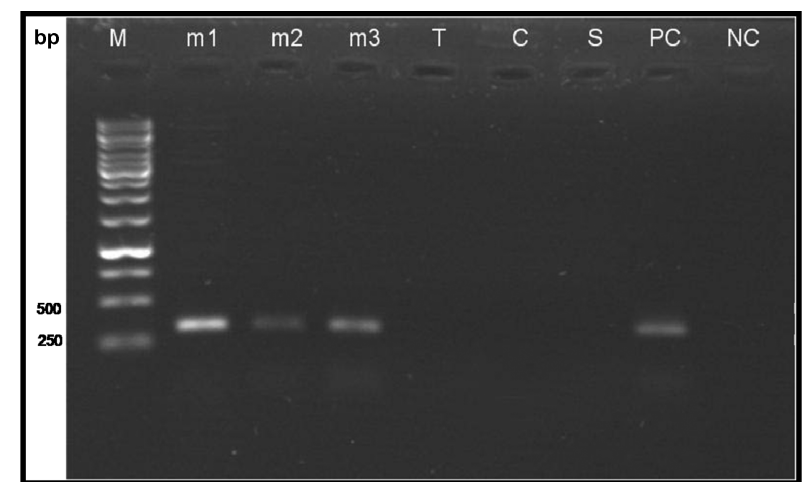

Fig. 2. Identification of $M$. phaseolina isolates using speciesspecific primers (MpKFI/MpKRI), M: $1 \mathrm{~kb}$ molecular ladder; m1-m3: M. phaseolina isolates from Iran; T: Trichoderma harzianum, C: Cytospora schusleri, and S: Sclerotinia sclerotiorum, are negative controls; PC: positive control marker isolate of M. phaseolina; NC: negative control without DNA 


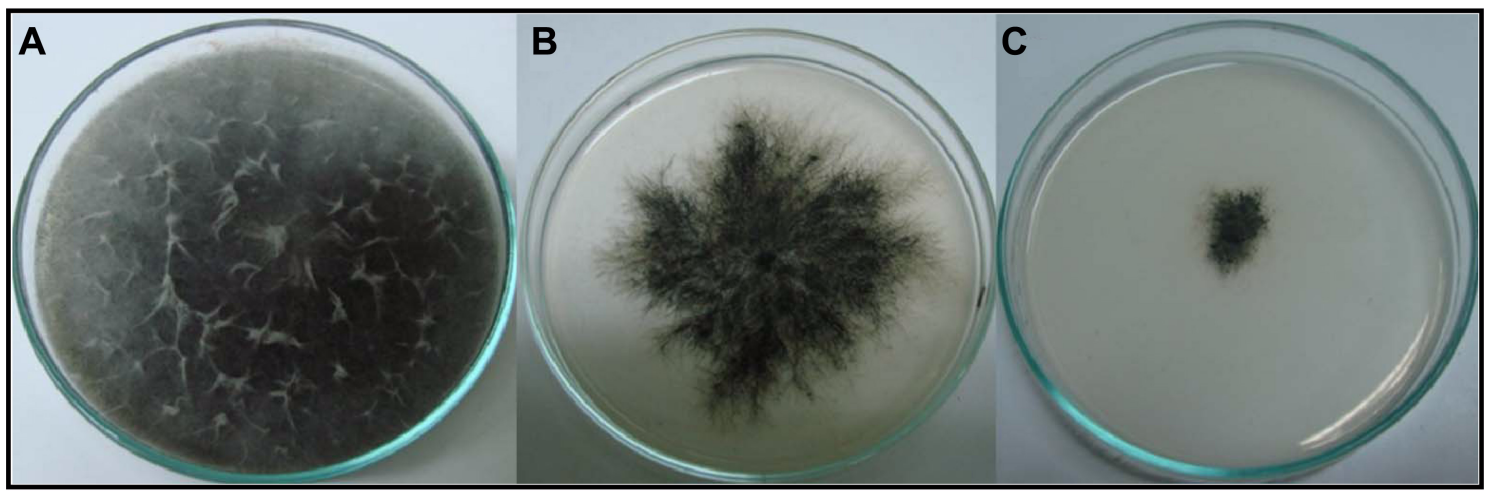

Fig. 3. Colony phenotypes of Macrophomina phaseolina isolates grown on PDA amended with $120 \mathrm{mM}$ potassium chlorate. A. dense colony phenotype $\mathrm{B}$. feathery colony phenotype and $\mathrm{C}$. restricted colony phenotype

Morphological analysis. The morphological characteristics of the recovered isolates were investigated, including colony phenotype on medium containing $120 \mathrm{mM}$ potassium chlorate (Fig. 3) (Pearson et al., 1986), relative growth rate at $30{ }^{\circ} \mathrm{C}$ and $37^{\circ} \mathrm{C}$ (Beas-Fernandez et al., 2006; MayekPerez et al., 1997), height of aerial mycelium, average length and width of 50 microsclerotia, and time to microsclerotia formation.

Genomic DNA extraction. Isolates were grown in the dark at $28^{\circ} \mathrm{C}$ for 5 days in $250 \mathrm{ml}$ glass bottles containing $50 \mathrm{ml}$ potato dextrose broth (PDB). Mycelia were filtered through Whatman No. 1 filter paper and lyophilized by vacuum pump. Genomic DNA was extracted according to Lee and Taylor (1990) with some modifications (excluding phenolchloroform step) as described by Safaie et al. (2005). DNA concentrations were determined by BioPhotometer at 260 $\mathrm{nm}$ and were stored at $-20^{\circ} \mathrm{C}$ for further use.

PCR amplification and gel electrophoresis. ISSR analysis was carried out amplifying the genomic DNA using ISSR primers (Table 1). The PCR amplification conditions were: initial denaturation at $95^{\circ} \mathrm{C}$ for 3 min followed by 35 cycles of denaturation at $94^{\circ} \mathrm{C}$ for $2 \mathrm{~min}$, primer annealing according to Table 1 for $1 \mathrm{~min}$, primer extension at $72^{\circ} \mathrm{C}$ for 2 $\mathrm{min}$, and a final primer extension at $72{ }^{\circ} \mathrm{C}$ for $7 \mathrm{~min}$. The amplification product was separated in a $1.5 \%$ agarose gel. The gel was stained with ethidium bromide $(0.50 \mu \mathrm{g} / \mathrm{ml})$ and visualized under UV to confirm DNA amplification. Amplifications and gel separation were repeated at least twice with each primer. A total of nine primers were screened initially. Six primers were selected for final analysis based on informative banding patterns, clarity, and repeatability.

Statistical analysis. Statistical analysis of morphological characteristics was performed in SAS.9.1.3.Service Pack 2. Means comparisons were performed by Duncan's Multiple Range Test. Relatedness among the 52 isolates was estimated by comparing the amplified DNA bands across the six

Table 1. List of ISSR primers, their annealing temperatures, and the resulted DNA polymorphisms applied to differentiate isolates of $M$. phaseolina

\begin{tabular}{|c|c|c|c|c|c|c|}
\hline Primer & Primer sequence ('5-3') & $\begin{array}{c}\text { Annealing } \\
\text { temperature } \\
\left({ }^{\circ} \mathrm{C}\right)\end{array}$ & $\begin{array}{l}\text { No. of ampli- } \\
\text { fied DNA } \\
\text { fragments }\end{array}$ & $\begin{array}{l}\text { No. of poly- } \\
\text { morphic frag- } \\
\text { ments }\end{array}$ & $\begin{array}{l}\text { Percent poly- } \\
\text { morphic frag- } \\
\text { ments }\end{array}$ & Reference \\
\hline ISSR2 & 5'-ACTGACTGACTGACTG-3' & 48 & 26 & 22 & 84.6 & Jana et al., 2005 \\
\hline ISSR5 & 5'-GACACGACACGACACGACAC-3' & 50 & 25 & 21 & 84.0 & Jana et al., 2005 \\
\hline ISSR10 & 5'-CACCACCACCACCAC-3' & 52 & 20 & 18 & 90.0 & Jana et al., 2005 \\
\hline PcMs & 5'-GTCGTCGTCGTCGTCGTCGTC-3 & 57 & 20 & 18 & 90.0 & Islam et al., 2003 \\
\hline ISSR09 & 5'-CCACCACCACCACCA-3' & 47 & 17 & 14 & 82.4 & Vasserur et al., 2005 \\
\hline P4 & 5'-ATGATGATGATGATGATG-3' & 47 & 16 & 14 & 87.5 & Stepansky et al., 1999 \\
\hline P5 & 5'-ACACACACACACACACYC-3' & - & - & - & - & Stepansky et al., 1999 \\
\hline P6 & 5'-GAGAGAGAGAGAGAGAYG-3' & - & - & - & - & Stepansky et al., 1999 \\
\hline LB-B & 5'-GACAGACAGACAGACATT-3 & - & - & - & - & Arbaoui et al., 2008 \\
\hline Total & - & - & 124 & 108 & 87.1 & - \\
\hline
\end{tabular}


Table 2. Host-, geographic-origins, and morphological characteristics of the studied M. phaseolina isolates of Iran

\begin{tabular}{|c|c|c|c|c|c|c|c|c|}
\hline Isolate No. & Host & Location & $\begin{array}{c}\text { Colony } \\
\text { morphology }\end{array}$ & $\begin{array}{l}\text { Chlorate } \\
\text { sensitivity }\end{array}$ & $\begin{array}{c}\text { Growth rate } \\
\text { at } 30^{\circ} \mathrm{C}(\mathrm{mm} / \mathrm{hr})\end{array}$ & A & B & $\mathrm{C}$ \\
\hline 1 & Sunflower & Khozestan & Feathery & Sensitive & 1.385 & $\mathrm{M}$ & & \\
\hline 2 & Sunflower & Fars & Restricted & Sensitive & 1.156 & $\mathrm{~L}$ & & \\
\hline 3 & Sunflower & Markazi & Restricted & Sensitive & 0.906 & $\mathrm{~L}$ & + & \\
\hline 4 & Soybean & Golestan & Feathery & Sensitive & 1.021 & $\mathrm{M}$ & + & \\
\hline 5 & Soybean & Golestan & Restricted & Sensitive & 0.833 & $\mathrm{M}$ & + & \\
\hline 6 & Soybean & Golestan & Restricted & Sensitive & 1.115 & M & & \\
\hline 7 & Olive & Khozestan-bagh malek & Feathery & Sensitive & 1.323 & $\mathrm{H}$ & & + \\
\hline 8 & Olive & Khozestan-haftapeh & Feathery & Sensitive & 1.448 & $\mathrm{M}$ & & + \\
\hline 9 & Olive & Khozestan-ahvaz & Feathery & Sensitive & 1.135 & $\mathrm{M}$ & & + \\
\hline 10 & Cantaloupe & Khorasan & Restricted & Sensitive & 1.198 & $\mathrm{M}$ & & \\
\hline 11 & Cantaloupe & Fars & Dense & Resistant & 1.083 & $\mathrm{~L}$ & & + \\
\hline 12 & Cantaloupe & Isfahan-kashan & Dense & Resistant & 1.240 & $\mathrm{M}$ & & \\
\hline 13 & Common Bean & Khorasan & Feathery & Sensitive & 1.302 & $\mathrm{M}$ & & + \\
\hline 14 & Common Bean & Isfahan & Feathery & Sensitive & 1.115 & $\mathrm{~L}$ & & + \\
\hline 15 & Common Bean & Ghazvin & Restricted & Sensitive & 1.010 & $\mathrm{H}$ & + & \\
\hline 16 & Tomato & Khorasan & Restricted & Sensitive & 1.240 & $\mathrm{~L}$ & & \\
\hline 17 & Tomato & Qom & Feathery & Sensitive & 1.219 & $\mathrm{H}$ & & \\
\hline 18 & Tomato & Ghazvin & Feathery & Sensitive & 1.125 & $\mathrm{M}$ & & + \\
\hline 19 & Cucumber & Tehran-karaj & Dense & Resistant & 1.542 & $\mathrm{~L}$ & & \\
\hline 20 & Cucumber & Hamedan & Restricted & Sensitive & 1.010 & $\mathrm{~L}$ & & \\
\hline 21 & Cucumber & Qom & Feathery & Sensitive & 1.292 & $\mathrm{H}$ & & \\
\hline 22 & Melon & Khorasan & Restricted & Sensitive & 1.458 & $\mathrm{H}$ & & \\
\hline 23 & Melon & Semnan & Dense & Resistant & 1.104 & $\mathrm{~L}$ & & \\
\hline 24 & Melon & Qom & Feathery & Sensitive & 1.260 & $\mathrm{M}$ & + & \\
\hline 25 & Sesame & Isfahan-kashan & Feathery & Sensitive & 1.406 & $\mathrm{H}$ & & \\
\hline 26 & Sesame & Khozestan & Feathery & Sensitive & 1.500 & $\mathrm{M}$ & & + \\
\hline 27 & Sesame & Kerman & Feathery & Sensitive & 0.844 & $\mathrm{~L}$ & + & \\
\hline 28 & Kiwi & Golestan & Feathery & Sensitive & 1.010 & M & + & \\
\hline 29 & Kiwi & Golestan & Feathery & Sensitive & 0.990 & $\mathrm{M}$ & + & \\
\hline 30 & Kiwi & Golestan & Feathery & Sensitive & 0.927 & $\mathrm{M}$ & + & + \\
\hline 31 & Hemp & Isfahan-kashan & Feathery & Sensitive & 1.385 & M & & + \\
\hline 32 & Hemp & Isfahan & Restricted & Sensitive & 1.125 & $\mathrm{M}$ & & \\
\hline 33 & Hemp & Isfahan & Feathery & Sensitive & 1.188 & $\mathrm{~L}$ & & \\
\hline 34 & Pumpkin & Markazi & Feathery & Sensitive & 1.344 & M & & \\
\hline 35 & Pumpkin & Ghazvin & Feathery & Sensitive & 1.208 & $\mathrm{M}$ & & \\
\hline 36 & Pumpkin & Ghazvin & Feathery & Sensitive & 1.177 & $\mathrm{M}$ & & + \\
\hline 37 & Mungbean & Kerman & Feathery & Sensitive & 1.146 & $\mathrm{M}$ & & \\
\hline 38 & Mungbean & Kerman & Feathery & Sensitive & 1.250 & $\mathrm{~L}$ & & \\
\hline 39 & Mungbean & Kerman & Feathery & Sensitive & 1.208 & M & & \\
\hline 40 & Okra & Khozestan & Feathery & Sensitive & 1.406 & $\mathrm{M}$ & & \\
\hline 41 & Okra & Yazd & Feathery & Sensitive & 1.073 & $\mathrm{~L}$ & & \\
\hline 42 & Sugar beet & Khorasan-fariman & Dense & Resistant & 1.240 & $\mathrm{~L}$ & & \\
\hline 43 & Canola & Qom & Feathery & Sensitive & 0.948 & $\mathrm{H}$ & & \\
\hline 44 & Datura & Markazi & Feathery & Sensitive & 1.021 & $\mathrm{~L}$ & & \\
\hline 45 & Eggplant & Hormozgan & Feathery & Sensitive & 1.260 & $\mathrm{~L}$ & & \\
\hline 46 & Sonchus & Tehran-karaj & Restricted & Sensitive & 1.219 & $\mathrm{H}$ & + & + \\
\hline 47 & Maize & Isfahan-kashan & Feathery & Sensitive & 1.115 & $\mathrm{H}$ & & \\
\hline 48 & Maize & Golestan & Feathery & Sensitive & 1.333 & M & & + \\
\hline 49 & Watermelon & Isfahan-kashan & Feathery & Sensitive & 1.021 & $\mathrm{H}$ & & + \\
\hline 50 & Marigold & Golestan & Restricted & Sensitive & 1.198 & $\mathrm{H}$ & & + \\
\hline 51 & Sorghum & Golestan & Feathery & Sensitive & 1.271 & $\mathrm{M}$ & & \\
\hline 52 & Turnip & Isfahan-kashan & Feathery & Sensitive & 1.115 & $\mathrm{~L}$ & & + \\
\hline
\end{tabular}

A: Height of aerial mycelium: $\mathrm{L}=$ low $(0 \mathrm{~mm}), \mathrm{M}=$ moderate $(1-2 \mathrm{~mm}), \mathrm{H}=$ high $(>2 \mathrm{~mm})$. B: Isolates with microsclerotia formed before $48 \mathrm{~h}$ of incubation at $37^{\circ} \mathrm{C}, \mathrm{C}$ : Isolates with microsclerotia formed after $60 \mathrm{hr}$ of incubation at $37^{\circ} \mathrm{C}$ 
ISSR primers. Each band was considered either present (coded as 1 ) or absent (coded as 0 ). The binary data were analyzed using the NTSYS-pc (Numerical Taxonomy and Multivariate Analysis System) package (Rholf, 2000) to determine the similarities among individuals. Similarities were estimated using Jaccard's (J) coefficient (Jaccard, 1908). Clustering analysis was performed using NTSYS-PC software programs by the unweighted pair-group method using arithmetic averages (UPGMA).

\section{Results and Discussion}

Fungal isolates. Fifty two Macrophomina phaseolina isolates were recovered from 24 plant species collected from the 14 Iranian provinces (Fig. 1 and Table 2). This was the first report of $M$. phaseolina from hemp, turnip, okra, mungbean, marigold and Sonchus in Iran. The speciesspecific primers designed by Babu et al. (2007) amplified one $350 \mathrm{bp}$ band in all isolates of Macrophomina, confirming that the isolates obtained belonged to the species $M$. phaseolina. No bands were present in the negative controls, confirming that the primers were specific to M. phaseolina. In most cases, we selected three isolates from each host, but from different regions, to try to determine whether isolates of one host from three regions have host-specific fingerprint profiles, this is an insight into host specialization.
Morphological analysis. Most $M$. phaseolina isolates $(67.3 \%)$ were characterized by feathery colony phenotype when grown on PDA medium containing $120 \mathrm{mM}$ potassium chlorate while $9.6 \%$ of the isolates showed dense growth and $23.1 \%$ of the isolates showed restricted growth (Table 2). Isolates characterized with a dense growth phenotype were considered resistant to chlorate, while isolates characterized with feathery or restricted growth phenotype were considered resistant to chlorate. All resistant isolates, except one, were collected from cucurbitaceous host plants, the exception was collected from sugar beet. All isolates from olive, kiwi, pumpkin, mungbean, tomato, okra and maize had a feathery phenotype, while two isolates from sunflower and soybean had a restricted phenotype (Table 2). Isolates were characterized according to the height of aerial mycelium when grown in PDA culture. Low aerial mycelium measured $0 \mathrm{~mm}$, medium aerial mycelium measured 1-2 $\mathrm{mm}$, and high aerial mycelium measured greater than 2 $\mathrm{mm}$. Among the isolates collected in Iran, 30.8\% had low aerial mycelium, $48.1 \%$ were moderate, and $21.2 \%$ had high aerial mycelium (Table 2). Isolates No.10 and No.12 had the largest microsclerotia, and isolates No.41 and No.27 had the smallest microsclerotia. Isolates from common bean (No.13, No.14 and No.15), maize (No.47 and No.48), mungbean (No.38 and No.39), kiwi (No.29 and No.30), cucumber (No.19 and No.20), olive (No.8 and No.9), sun-

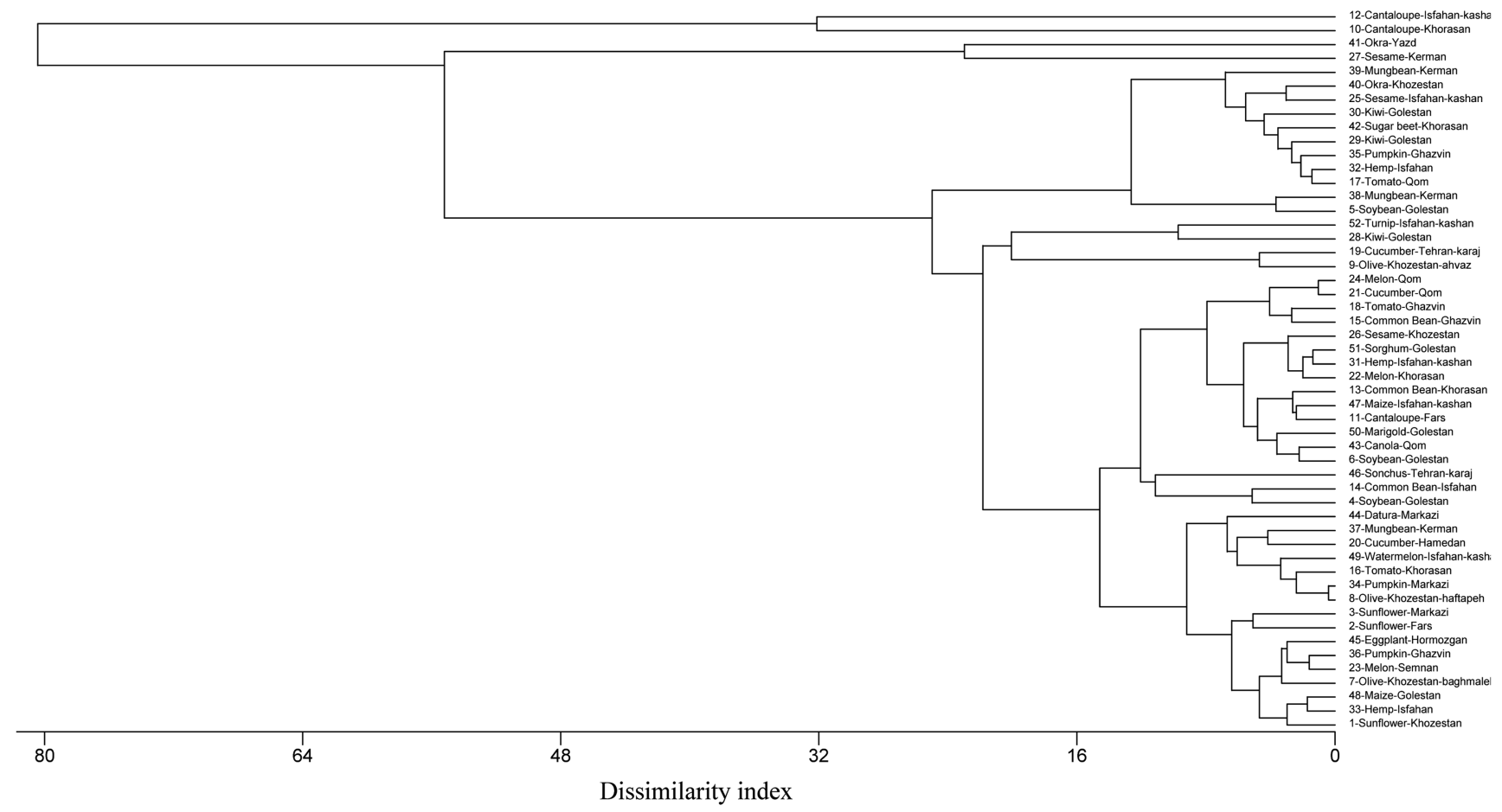

Fig. 4. Dendrogram constructed with UPGMA clustering method for 52 Macrophomina phaseolina recovered from different provinces in Iran. Dissimilarities were computed from chlorate phenotype, relative growth rate at $30^{\circ} \mathrm{C}$ and $37^{\circ} \mathrm{C}$, height of aerial mycelium, average length and width of 50 microsclerotia, and time of microsclerotia formation. 
flower (No.1 and No.3), soybean (No.4 and No.6) and hemp (No.31 and No.33) have the same size of sclerote and grouped according to host. Finally, isolates were clustered using all morphological characteristics (Fig. 4).

All the dense chlorate-resistant isolates, except one, were recovered from cucurbitaceous hosts, the exception was collected from sugar beet in Khorasan province. Chlorate is an analog of nitrate, and the reduction of chlorate via nitrate reductase can result in chlorate toxicity in plants, algae, bacteria and fungi. Chlorate-sensitive strains can reduce nitrate to nitrite, and the chlorate resistant strains cannot (Pearson et al., 1986). All isolates from olive, kiwi, pumpkin, mungbean, tomato, okra and maize were sensitive to chlorate, as recognized by the feathery phenotype on potassium chlorate medium. These results support reports that isolates of the same host species usually have the same colony phenotype (Cloud and Rupe, 1994; Pearson et al., 1987; Purkayastha et al., 2006; Su et al., 2001). As observed among M. phaseolina isolates from olive, kiwi, pumpkin, mungbean, tomato, okra and maize, the association of chlorate sensitivity and host may be due to the selection pressure posed by the host over time. Host-specific isolates may have had time to establish a genetic change based on the physiology of nitrogen utilization in the host. However, colony phenotype of $M$. phaseolina isolates of cucumber and melon grown on chlorate medium was not consistent within each host. The host from which an isolate was collected may not be the only host to which the isolate was exposed (Pearson et al., 1986). Inorganic nitrate serves as an excellent nitrogen source for many fungi, including $M$. phaseolina, but it is generally not utilized unless the cells lack a favored nitrogen source, such as ammonia, glutamine or glutamate (Dhingra and Sinclair, 1978; Marzluf, 1997). Maximum invasion in Macrophomina took place during the grain development stages because of competition for carbohydrates with developing grains that physiologically weaken the plant (Dodd, 1980). Under such conditions it is highly probable that fungi might utilize nitrate as a source of nitrogen (Das et al., 2006).

ISSR analysis. DNA fragments that resulted from amplification with six ISSR primers ranged in size from 250 to $3,300 \mathrm{bp}$ (Fig. 5). The number of bands ranged from 16 to 26 , of which $84-90 \%$ were polymorphic (Table 1). Dendrogram of pooled six primers data is presented in Fig. 6 . Based on the resulting dendrogram, isolates did not clearly differentiate to the specific group according to the host or geographical origins, however, usually the isolates from the same host or the same geographic origin tend to group nearly. For example, isolates from hosts olive (No.7 and No.8), sunflower (No.2 and No. 3), Kiwi (No.28, No.29 and No. 30), mungbean (No.38 and No.39), hemp (No.32

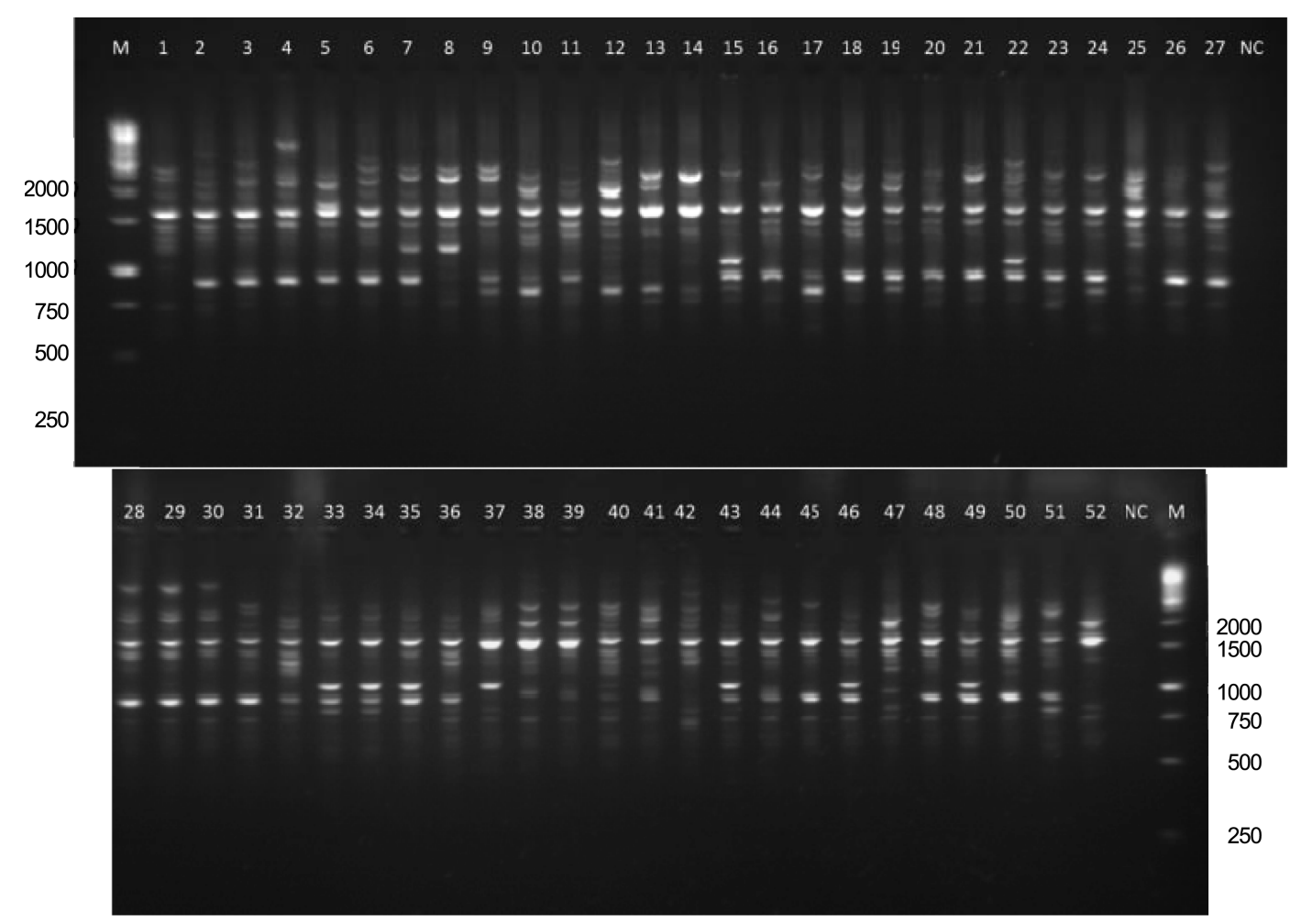

Fig. 5. ISSR banding pattern of 52 Macrophomina phaseolina isolates generated by primer PCMS (B). M: standard 1kb molecular ladder, NC: negative control without DNA. 


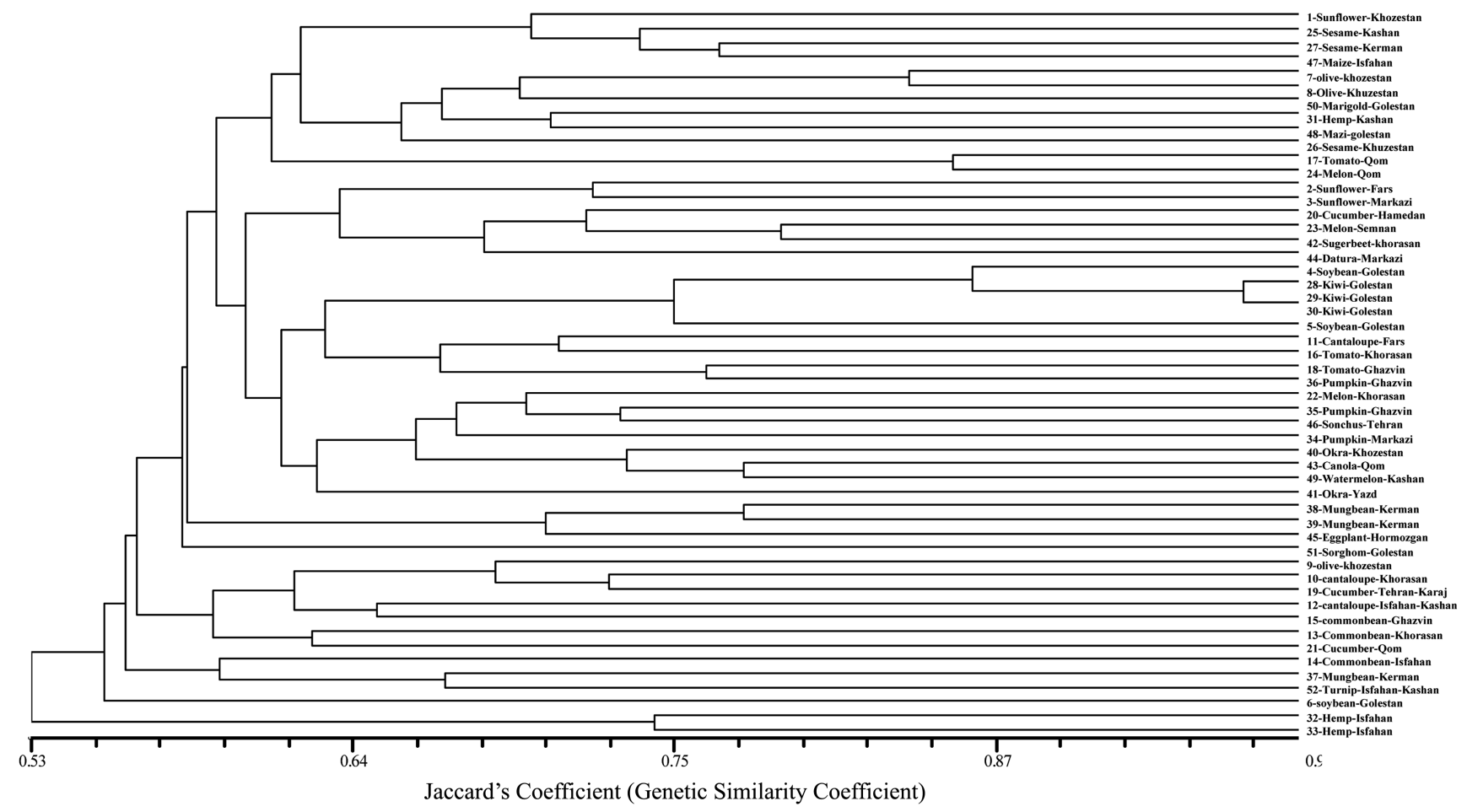

Fig. 6. Dendrogram of 52 isolates of Macrophomina phaseolina derived from ISSR analysis with all six primers by UPGMA.

and No.33) and isolates from provinces Qom (No.17 and No.24), Golestan (No.4, No.28, No.29, No.30 and No.5), Ghazvin (No.18 and No.26), Kerman (No.38 and No.39), Isfahan (No.32 and No.33) appeared to be closely related (Fig. 6).

The ISSR technique is an appropriate molecular analysis approach to identify genetic differences in M. phaseolina populations (Jana et al., 2005a). The results of the present study clearly demonstrated that $M$. phaseolina from different parts of the country were highly variable and ISSR markers are suitable to reflect the genetic diversity among the populations. A number of molecular studies elsewhere have shown a high level of polymorphism in this fungus when isolates from different host or geographical origins were compared using different molecular tools (Almeida et al., 2003; Jones et al., 1998; Mayek-Perez et al., 2001; Su et al., 2001; Vandemark et al., 2000). Other recent studies have demonstrated the genetic diversity among $M$. phaseolina isolates (Aboshosha et al., 2007; Aghakhani and Dubey, 2009; Babu et al., 2010; Baird et al., 2010; Beas-Fernandez et al., 2006; Das et al., 2006; Jana et al., 2005a; Jana et al., 2005b; Omar et al., 2007; Purkayastha et al., 2008; Rajkumar and Kuruvinashetti, 2007; Reyes-Franco et al., 2006; Saleh et al., 2010). The high genetic diversity of this pleomorphic fungal species is reflected not only in isolates from distinct hosts and geographical origins but also within isolates collected from a single host or geographical origin. The activity of transposons and a high mutation rate of microsatellites could be crucial for genetic variability generated by parasexual reproduction of the fungi (Purkayastha et al., 2008). Based on the resulting dendrogram for ISSR markers, the isolates were not completely differentiated to specific groups according to host or geographical origins. However, usually isolates from the same host or origin tend to group together. Several studies have found no association between DNA genotype and host origin in populations (Almeida et al., 2003; Reyes-Franco et al., 2006; Vandemark et al., 2000). Recently Saleh et al. (2010) used AFLP markers and ITS region sequences to assess the genetic diversity and relationships of M. phaseolina isolates from maize, sorghum, tallgrass prairie and soybean. Using Bayesian cluster analysis based on the estimation of co-ancestry coefficients they demonstrated the incomplete specialization by host in charcoal rot fungus, in contrast to results reported by earlier studies (Jana et al., 2003; Jana et al., 2005a; Jana et al., 2005b; Mayek-Perez et al., 2001; Su et al., 2001). Recently, Baird et al. (2010) used twelve simple sequence repeat (SSRs) loci to evaluate genetic diversity of M. phaseolina collected from different geographical regions and host species throughout the United States. Their results showed some clustering by host and geography, but the dendrogram generally grouped isolates independent of host or geography. Three Primers in the present study, ISSR2, ISSR5, and ISSR10, were used by Jana et al. (2005a) to separate 
isolates according to their hosts and geographical origins. Unlike the present study, these primers did not completely separate isolates according to their hosts. The controversial results could be due to the high number of isolates and hosts in our study compared to theirs. Isolates from hosts olive (No.7 and No.8), sunflower (No.2 and No. 3), Kiwi (No.28, No.29 and No. 30), mungbean (No.38 and No.39), hemp (No.32 and No.33) and isolates from provinces Qom (No.17 and No.24), Golestan (No.4, No.28, No.29, No.30 and No.5), Ghazvin (No.18 and No.26), Kerman (No.38 and No.39), Isfahan (No.32 and No.33) were closely related (Fig. 6). In part similar to our results, several other studies have found an association between DNA genotype and host or geographic origin in populations (Jana et al., 2003; Jana et al., 2005a; Jana et al., 2005b; Mayek-Perez et al., 2001; Purkayastha et al., 2006; Su et al., 2001). The present findings are partially in accordance with the earlier results that the M. phaseolina isolates of same host were genetically similar and differed distinctly from the isolates of other hosts (Purkayastha et al., 2006; Su et al., 2001). The existence of genetic diversity among the isolates from the same provinces might be due to the movement of $M$. phaseolina through infested seeds and soil (Aghakhani and Dubey, 2009). Some of the isolates within a province showed similarity suggesting that these isolates may be considered as a part of the same ancestral population (Almeida et al., 2003).

\section{Conclusion}

A considerable degree of diversity was revealed in the Iranian population of M. phaseolina in the present study. It is suggest that this enhanced its ability to adapt to diverse conditions and overcome host resistance deployed by growers (Trigiano et al., 2008). Basic morphological characteristics are the primary tools to detect diversity in all organisms; however, such morphological phenotypes are subjected to modification by environmental factors or by interaction with products of unknown genes in the genetic background. Molecular markers are ideal tools for assessing variation rapidly within and among species (Chakravarthi and Naravaneni, 2006). In the present study, $52 \mathrm{M}$. phaseolina isolates were recovered from 24 host plant species throughout 14 Iranian provinces surveyed. All isolates were confirmed to species based on speciesspecific primers according to Babu et al. (2007).

Our results revealed that like M. phaseolina populations in other countries; the Iranian populations are highly diverse based on phenotypic and genotypic data. High levels of variability are most likely due to the exposure of the pathogen to diverse climates, hosts, cropping patterns and movement of the pathogen within the country. In recent years the country has experienced severe drought conditions possibly due to global warming. M. phaseolina capable of becoming a severe problem in many regions and on several host plants, it is tempting to call it a "global warming plant pathogen" as this may influence its curent importance in countries such as Iran.

\section{References}

Aboshosha, S. S., Attaalla, S. I., El-Korany, A. E. and El-argawy, E. 2007. Characterization of Macrophomina phaseolina isolates affecting sunflower growth in El-Behera governorate, Egypt. Int. J. Agric. Biol. 9:807-815.

Aghakhani, M. and Dubey, S. C. 2009. Determination of genetic diversity among Indian isolates of Rhizoctonia bataticola causing dry root rot of chickpea. Anton Leeuw Int. J. G. 96: 607-619.

Almeida, A. M. R., Abdelnoor, R. V., Arias, C. A. A., Carvalho, V. P., Martin, S. R. R., Benato, L. C., Pinto, M. C. and Carvalho, C. G. P. 2003. Genotypic diversity among brazilian isolates of Macrophomina phaseolina revealed by RAPD. Fitopatol. Bras. 28:279-285.

Almeida, M. R., Sosa-Gomez, D. R., Binneck, E., Marin, S. R. R., Zucchi, M. I., Abdelnoor, R. V. and Souto, E. R. 2008. Effect of crop rotation on specialization and genetic diversity of Macrophomina phaseolina. Trop. Plant Pathol. 33:257-264.

Babu, B. K., Reddy, S. S., Yadav, M. K., Sukumar, M., Vijendra, M., Saxena, A. K. and Arora, D. K. 2010. Genetic diversity of Macrophomina phaseolina isolates from certain agro-climatic regions of India by using RAPD markers. Indian J. Microbiol. 50:199-204.

Babu, B. K., Saxena, A. K., Srivastava, A. K. and Arora, D. K. 2007. Identification and detection of Macrophomina phaseolina by using species-specific oligonucleotide primers and probe. Mycologia 99:797-803.

Baird, R. E., Wadl, P. A., Allen, T., McNeill, D., Wang, X. W., Moulton, J. K., Rinehart, T. A., Abbas, H. K., Shier, T. and Trigiano, R. N. 2010. Variability of United States isolates of Macrophomina phaseolina based on simple sequence repeats and cross genus transferability to related genera within Botryosphaeriaceae. Mycopathologia 170:169-180.

Beas-Fernandez, R., De Santiago-De Santiago, A., HernandezDelgado, S. and Mayek-Perez, N. 2006. Characterization of Mexican and non-Mexican isolates of Macrophomina phaseolina based on morphological characteristics, pathogenicity on bean seeds and endoglucanase genes. J. Plant Pathol. 88:5360.

Brooker, N., Lord, J. R., Long, J. and Jayawardhana, A. 2008. AFLP analysis of genetic diversity in charcoal rot fungal populations impacted by crop rotations. Commun. Agric. Appl. Biol. Sci. 73:7-19.

Chakravarthi, B. K. and Naravaneni, R. 2006. SSR marker based DNA fingerprinting and diversity study in rice (Oryza sativa. L.). Afr. J. Biotechnol. 5:684-688.

Cloud, G. L. and Rupe, J. C. 1994. Influence of nitrogen, plant growth stage, and environment on charcoal rot of grain sor- 
ghum caused by Macrophomina phaseolina (Tassi) Goid. Plant Soil 158:203-210.

Das, I. K., Fakrudin, B. and Arora, D. K. 2006. RAPD cluster analysis and chlorate sensitivity of some Indian isolates of Macrophomina phaseolina from sorghum and their relationships with pathogenicity. Microbiol. Res. 163:215-224.

Dhingra, O. D. and Sinclair, J. B. 1972. Variation among isolates of Macrophomina phaseoli (Rhizoctonia bataticola) from the same soybean plant. Phytopathology 62:1108-1115.

Dhingra, O. D. and Sinclair, J. B. 1978. Biology and pathology of Macrophomina phaseolina. Imprensa Universitária, Universidade Federal de Viçosa, Viçosa, Brasil. 166 pp.

Dodd, J. L. 1980. The photosynthetic stress-translocation balance concept of sorghum stalk rots. International Workshop on Sorghum Diseases, Patancheru, ICRISAT, India, pp. 300-305.

Edmunds, L. K. 1964. Combined relation of plant maturity, temperature, and soil moisture to charcoal stalk rot development in grain sorghum. Phytopathology 54:514-517.

Hawatema, M. S. and Hameed, K. M. 2006. Morphological and molecular studies on charcoal rot (Macrophomina phaseolina) in Jordan. Phytopathology 96:S46-S47.

Jaccard, P. 1908. Nouvelles researches sur la distribution florale. Societe Vaudoise des Sciences Naturelles Bulletin 44:223270.

Jana, T., Sharma, T. R., Prasad, R. D. and Arora, D. K. 2003. Molecular characterization of Macrophomina phaseolina and Fusarium species by a single primer RAPD technique. Microbiol. Res. 158:249-257.

Jana, T., Sharma, T. R. and Singh, N. K. 2005a. SSR-based detection of genetic variability in the charcoal root rot pathogen Macrophomina phaseolina. Mycol. Res. 109:81-86.

Jana, T., Singh, N., Koundal, K. and Sharma, T. 2005b. Genetic differentiation of charcoal rot pathogen, Macrophomina phaseolina, into specific groups using URP-PCR. Can. J. Microbiol. 51:159-164.

Jones, R. W., Canada, S. and Wang, H. 1998. Highly variable minichromosomes and highly conserved endoglucanase genes in the phytopathogenic fungus Macrophomina phaseolina. Can. J. Bot. 76:694-698.

Karunanithi, K., Muthusamy, M. and Seetharaman, K. 1999. Cultural and pathogenic variability among the isolates of Macrophomina phaseolina causing root rot of sesamum. Plant Dis. Res. 14:113-117.

Lee, S. B. and Taylor, J. W. 1990. Isolation of DNA from fungal mycelia and single spores. In: PCR Protocols: a guide to methods and applications, ed. by Innis, M. A., Gelfand, D. H., Sinsky, J. J., White, T. J., pp. 282-287. Academic Press, New York.

Marzluf, G. A. 1997. Genetic regulation of nitrogen metabolism in the fungi. Microbiol. Mol. Biol. Rev. 61:17-32.

Mayek-Perez, N., Lopez-Castaneda, C. and Acosta-Gallegos, J. A. 1997. Variation in vitro cultural characteristics of Macrophomina phaseolina isolates and its virulence on common bean. Agrociencia 31:187-195.

Mayek-Perez, N., Lpez-Castaeda, C., Gonzglez-Chavira, M., Garcia-Espinosa, R., Acosta-Gallegos, J., de la Vega, O. M. and
Simpson, J. 2001. Variability of Mexican isolates of Macrophomina phaseolina based on pathogenesis and AFLP genotype. Physiol. Mol. Plant Pathol. 59:257-264.

Mihail, J. D. and Taylor, S. J. 1995. Interpreting variability among isolates of Macrophomina phaseolina in pathogenicity, pycnidium production, and chlorate utilization. Can. J. Bot. 73: 1596-1603.

Omar, M. R., Abd-Elsalam, K. A., Aly, A. A., El-Samawaty, A. M. A. and Verreet, J. A. 2007. Diversity of Macrophomina phaseolina from cotton in Egypt: Analysis of pathogenicity, chlorate phenotypes, and molecular characterization. Z. Pflanzenk. Pflanzen. 114:196-204.

Pearson, C. A. S., Leslie, J. F. and Schwenk, F. W. 1986. Variable chlorate resistance in Macrophomina phaseolina from corn, soybean and soil. Phytopathology 76:646-649.

Pearson, C. A. S., Leslie, J. F. and Schwenk, F. W. 1987. Host preference correlated with chlorate resistance in Macrophomina phaseolina. Plant Dis. 71:828-831.

Purkayastha, S., Kaur, B., Arora, P., Bisyer, I., Dilbaghi, N. and Chaudhury, A. 2008. Molecular genotyping of Macrophomina phaseolina isolates: comparison of microsatellite primed PCR and repetitive element sequence-based PCR. J. Phytopathol. 156:372-381.

Purkayastha, S., Kaur, B., Dilbaghi, N. and Chaudhury, A. 2006. Characterization of Macrophomina phaseolina, the charcoal rot pathogen of cluster bean, using conventional techniques and PCR-based molecular markers. Plant Pathol. 55:106-116.

Raeyatpanah, S. and Forootan, A. 1993. Study of charcoal rot (Macrophomina phaseolina) in Mazandaran and reasons for its epidemic. $11^{\text {th }}$ Iranian Plant Protection Congress, Rasht, Iran, p. 116.

Raeyatpanah, S., Foroutan, A. and Oladi, M. 2002. Evaluation of soybean cultivars to charcoal rot caused by Macrophomina phaseolina (Tassi) Goid in Mazandaran. $15^{\text {th }}$ Iranian Plant Protection Congress, Isfahan, Iran, p. 117.

Rajkumar, F. B. and Kuruvinashetti, M. S. 2007. Genetic variability of sorghum charcoal rot pathogen (Macrophomina phaseolina) assessed by random DNA markers. Plant. Pathol. J. 23: 45-50.

Razavi, S. E. and Pahlavani, M. H. 2004. Isolation of the causal of charcoal rot disease of safflower and resistance of some cultivars to the disease. $16^{\text {th }}$ Iranian Plant Protection Congress, Tabriz, Iran.

Reyes-Franco, M. C., Hernandez-Delgado, S., Beas-Fernandez, R., Medina-Fernandez, M., Simpson, J. and Mayek-Perez, N. 2006. Pathogenic and genetic variability within Macrophomina phaseolina from Mexico and other countries. J. Phytopathol. 154:447-453.

Rholf, F. J. 2000. NTSYS-pc Numerical taxonomy and multivariate system version 2.1. Exeter publishing, Setauket.

Safaie, N., Alizadeh, A., Saidi, A., Rahimian, H. and Adam, G. 2005. Molecular characterization and genetic diversity among Iranian populations of Fusarium graminearum, the causal agent of wheat head blight. Iran. J. Plant Pathol. 41:171-189.

Saleh, A. A., Ahmed, H. U., Todd, T. C., Travers, S. E., Zeller, K. A., Leslie, J. F. and Garrett, K. A. 2010. Relatedness of Mac- 
rophomina phaseolina isolates from tallgrass prairie, maize, soybean and sorghum. Mol. Ecol. 19:79-91.

Su, G., Suh, S.-O., Schneider, R. W. and Russin, J. S. 2001. Host specialization in the charcoal rot fungus, Macrophomina phaseolina. Phytopathology 91:120-126.

Trigiano, R. N., Windham, M. T. and Windham, A. S. 2008. Plant pathology: concepts and laboratory exercises. CRC Press, Boca Raton.

Vandemark, G., Martinez, O., Pecina, V. and Alvarado, M. D. 2000. Assessment of genetic relationships among isolates of Macrophomina phaseolina using a simplified AFLP technique and two different methods of analysis. Mycologia 92:656664.

Zade, M. S. A., Zadeh, N. A., Nejad, R. F., Rezaee, S. and Mahmoudi, B. 2009. RAPD marker as a criterion to study differentiation of isolates of Rhizoctonia solani and Rhizoctonia bataticola (Macrophomina phaseolina). Phytopathology 99: 113-113.

Zietkiewicz, E., Rafalski, A. and Labuda, D. 1994. Genome fingerprinting by simple sequence repeat (SSR)-anchored polymerase chain reaction amplification. Genom. Genet. Wkly. 20: 176-183. 